\title{
Multi-objective optimisation model: A housing block retrofit in Seville
}

\author{
Patricia Edith Camporeale a,b,*, María del Pilar Mercader Moyano ${ }^{\mathrm{b}}$, \\ Jorge Daniel Czajkowski ${ }^{a}$
}

a Sustainable Architecture E Habitat Laboratory, Faculty of Architecture E Urbanism, National University of La Plata, Calle $42 n^{\circ} 162,1900$ La Plata, Argentina

${ }^{\mathrm{b}}$ Department of Architectural Construction I, Technical High School of Architecture, University of Seville, Avenida Reina Mercedes 1, 41012 Seville, Spain

\section{A R T I C L E I N F O}

\section{Article history:}

Received 27 April 2017

Received in revised form 7 August 2017

Accepted 9 August 2017

Available online 19 August 2017

\section{Keywords:}

Performance based-design

Building envelope

Multi-objective optimization

Thermal load indexes

\begin{abstract}
A B S T R A C T
Performance-driven optimization has shown its potential to integrate design and energy performance, since building shape and envelope are determinant to the energy demand. Even though new buildings should be nearly zero energy buildings by 2020, according to European Directive 2010/31 recast, they only represent a minority of the building stock. Building retrofit has demonstrated a great potential to reduce energy consumption, and at the same time, $\mathrm{CO}_{2}$ emissions.

The scope of this work is to present and test a design methodology to enable architects and decision makers to couple building shape and envelope with energy and financial performance in a multi-objective optimization method. Our multi-objective optimization model is adaptable for both conceptual design and building retrofit, and presents effective application to assist design decisions in a seamless workflow.

In this case study, we have applied the model to a housing block retrofit in Seville. We have designed indexes to optimise building envelope, considering mild climates issues. Then, we have simulated heating and cooling demand of the optimal solutions and calculated Net Present Value (NPV) to obtain their financial feasibility. The results have shown the robustness and validity of the framework.
\end{abstract}

(c) 2017 Elsevier B.V. All rights reserved.

\section{Introduction}

Due to the need to accomplish the Energy Performance of Buildings Directive (EPBD) recast [1], which prescribes that all new buildings must be nearly zero energy buildings (nZEB) by 2020 , Europe aims at making the building stock more energy efficient. Buildings account for $40 \%$ of the total energy consumption and $36 \%$ of $\mathrm{CO}_{2}$ emissions in Europe [2]. In fact, the tendency of these values is to increase if no measures are taken to revert it [3]. Even though new buildings would be nearly Zero Buildings (nZEB) by 2020, they only represent a minority of the building stock [4]. Building retrofit has demonstrated a great potential to reduce energy consumption, and at the same time, $\mathrm{CO}_{2}$ emissions [5]. In order to take advantage of this potential, Spain implemented the Law 8/2013, which regulates renovation, retrofitting and energy certification for existing buildings [6], according to European standards.

The building envelope plays a major role in energy efficiency and indoor environmental quality, and represents a big part of the bud-

\footnotetext{
* Corresponding author at: Sustainable Architecture \& Habitat Laboratory, Faculty of Architecture \& Urbanism, National University of La Plata, Calle $42 \mathrm{n}^{\circ} 162,1900$ La Plata, Argentina.

E-mail address: pcamporeale@fau.unlp.edu.ar (P.E. Camporeale).
}

get, having the same importance in the case of new or refurbished buildings. In the early design stages, building shape and envelope composition determine energy performance. However, the traditional design methodology that architects apply is mainly based on form and function, and not in performance-driven criteria. As there is an increasing scientific interest to provide performance-based methods, as pointed by Nguyen et al. [7], many researchers have presented the coupling of parametric design with building performance simulation (BPS) and optimization methods [8]. Even when it is broadly accepted that energy performance, efficiency and endcost are determinant in early stages, the same approach can also be applied in the case of building retrofits [9].

Until recently, many architects were not used to introducing performance-driven techniques at the conceptual design stage. Furthermore, performance-based methods were not user-friendly for most of them and remained in the domain of experts and researchers $[10,11]$. As personal computers became more powerful, performance simulation tools enabled more rapid analysis and more designers began to use them. As it is increasingly necessary to fill the gap between architects and digital tools, a feasible method should include a modelling platform, to make them feel familiar with simulation tools and optimization methods in a seamless workflow. There are several ways to address this issue combin- 
ing different BSP models and optimization algorithms. Parametric design coupled with building performance simulation (BPS) and optimization techniques enables architects and decision makers (DMs) to achieve more efficient buildings than those that would result from a traditional methodology. However, the main scope of this approach is the sorting of the different morphological proposals and not an accurate energy demand because the BPS models may require data that might not be available, especially in early stages [12].

Metaheuristics methods [13], among which we find genetic algorithms, have shown to be an appropriate way to deal with multi-objective issues such as environmental and energy performance [14]. Optimization algorithms have been largely developed: particle swarm, hill-climbing, simulated annealing, and genetic algorithms among others, as pointed by Russell [15]. John Holland developed genetic algorithms (GAs) that, based in evolutionary biology, simulate inheritance, mutation, selection, and crossover [16]. GAs have been tested to solve a wide variety of optimization problems and shown their pros and cons [17]. Researchers working on GA optimization - applied to architectural problems - have found that GAs are suitable when solving problems within a large search space, avoiding local optima [18]. Caldas coupled a building performance engine with a GA, using DOE2.1E and GenOpt [19]. Others groups have employed Non-dominated Sorting Genetic Algorithm-II (NSGA-II) and EnergyPlus [20] to solve multi-objective issues, when more than one goal must be achieved [21]. Lin et al. have integrated Revit ${ }^{\mathrm{TM}}$, Green Building Studio ${ }^{\mathrm{TM}}$, and Microsoft Excel $^{\mathrm{TM}}$ through H.S.Beagle ${ }^{\mathrm{TM}}$ plug-in, applying a multi-objective optimization method [22]. Gerber et al. have also experimented with methodologies that integrate multiple environments as 3D modelling program Rhinoceros [23], and the parametric plugin Grasshopper [24] together with Ladybug/Honeybee (C) to link Daysim/Radiance-EnergyPlus/Open Studio [25]. Asadi et al. have proposed another combination scheme: TRNSYS, GenOpt and a Tchebycheff optimization technique developed in MATLAB [26]. Ferrara et al. employed the same scheme to optimise nZEB buildings [27]. Asl et al. have explored the plug-in Dynamo to extend parameterization capabilities in Revit ${ }^{\mathrm{TM}}$, and Optimo, a free package which employs a NSGA-II [28].

Researchers have explored the possibilities of a scheme that integrates Rhinoceros, Grasshopper (GH), and GH evolutionary solver: Galapagos [29] and DIVA (Design, Iterate, Validate, Adapt) [30]. DIVA is a plug-in to connect Rhino/GH with EnergyPlus to perform thermal analysis and Daysim/Radiance, to perform daylight simulation [31]. As pointed by Ercan et al., [32], Galapagos has the limitation of optimizing one objective function at a time. Thus, in the case of multiple objective functions as generally occur with design problems, results must be post-processed. This evolutionary solver can minimise or maximise one or more variables in one fitness function. The mechanism of selection is biased so the chance of mating increases as the fitness increases; the gene transmission mechanism includes coalescence, which averages the values of the parents adding preferences, depending on their fitness. To avoid getting stuck in local optima, mutation can be manually introduced [33]. In former research, we have explored Rhinoceros/Grasshopper linked with Ecotect ${ }^{\mathrm{TM}}$ [34] and DIVA through Geco [35] [36].

Other authors have explored another methods like GA optimization combined with steady-state methods: degree-day (DDM) or degree-hour (DHM) methods [37], adding internal and solar gains to the thermal balance and not only envelope losses [38]. DDM has proved to be useful in cold and cloudy climates but not for sunny temperate ones, as in the case of Seville. The shape coefficient (SC) employed by DDM is the ratio of the building total external surface area to its internal volume and an indicator of energy demand. But as Depecker et al. [39] have pointed out, in mild climates, compactness is not directly proportional to heating demand; thus, during the winter, solar radiation incoming through the windows may overcompensate for the heat loss through the envelope. Furthermore, solar radiation on South façades (in the case of the Northern hemisphere) may even store heat depending on available thermal mass.

Despite the intention shown in the works mentioned above, performance based design methods have been circumscribed to the use of the researchers themselves without being tested by other users like designers. Thus, the impact of these frameworks outside controlled environments has remained unexplored and unexploited. Because of the gap in research, this work presents a framework to explore building shape/performance with the use of multi-objective optimization model (MOOM).

\section{Methodology}

The model is originally applied to new buildings in the early stages of the design process [40], and can be adapted to retrofit cases, where the exploration process is limited to the envelope components. This tool optimises design issues like building shape, envelope U-values, and window to wall ratio (WWR) to reduce energy demand. We integrate parametric design in Rhino/GH/Galapagos, using a MOOM, which has shown to be an appropriate tool to seize the contrasting objectives that must be addressed. The joint of Rhinoceros, Grasshopper, and Galapagos as a tool to explore building shape and performance - thanks to its ease of use and speed of processing - allows designers with no scripting knowledge to generate parametric models [33]. The method minimises heating/cooling demand to improve envelope performance, and maximises Net Present Value to improve financial performance. The scheme shows the model organization, divided in different steps as shown in Fig. 1. The project requirements comprehend building uses, occupancy schedule, site and climate data, current standards, and any other applicable parameter. These data are manually input to the 3D environment in Rhinoceros and parameterised in Grasshopper. The designer defines the initial shape through geometrical and topological rules that determine the building masses.

We build two indexes: one for heating loads, and another one for cooling loads, which account for the gains and losses for typical winter and summer days. They also consider the variation of the wind speed according to the roughness of the land and the different storey heights, and let the user apply different ventilation strategies according to air infiltration. The calculation process of $D_{\text {HEAT }}$ and $\mathrm{D}_{\mathrm{COOL}}$ requires to input the mean maximum and minimum temperatures for January and July to calculate the hourly temperatures using the coefficients provided by Gonzalo [41]. Other inputs are the opaque component absorptances to obtain the sol-air temperature. The model computes solar gains for each façade direction, changing SHGC when shading devices are active. The process follows the steps detailed in Argentine Standards IRAM 11659 1-2 to calculate the volumetric coefficient for cooling $[42,43]$, but carried out hour by hour, instead of only at solar peak hour. In our case, we calculate the ratio between hourly gains and losses addition and the useful floor area (Eqs. (1) and (2)):

$$
\begin{aligned}
& D_{H E A T}=1 / A \times \sum_{i=1}^{N}\left(Q_{E i}+Q_{A i}-Q_{S i}-Q_{O i}\right) \\
& D_{C O O L}=1 / A x \sum_{i=1}^{N}\left(Q_{E i}+Q_{A i}+Q_{S i}+Q_{O i}\right)
\end{aligned}
$$

$\mathrm{D}_{\text {HEAT }}=$ index of heating demand $\left(\mathrm{Wh} / \mathrm{m}^{2}\right.$ day $)$

$\mathrm{D}_{\mathrm{COOL}}=$ index of cooling demand $\left(\mathrm{Wh} / \mathrm{m}^{2}\right.$ day $)$

$\mathrm{A}=$ floor area $\left(\mathrm{m}^{2}\right)$ 


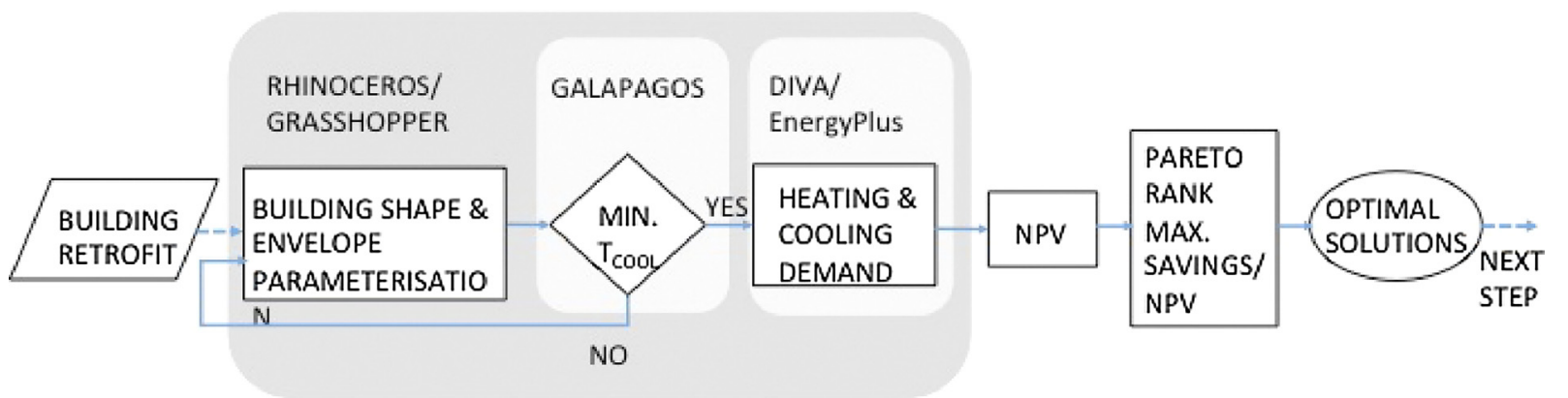

\section{Manual process}

Automated process

Fig. 1. Diagram showing the steps of the design methodology.

\section{$\mathrm{N}=24$}

$\mathrm{Q}_{\mathrm{Ei}}=$ hourly envelope losses/gains by transmission (Wh)

$\mathrm{Q}_{\mathrm{Ai}}=$ hourly air losses/gains (Wh)

$\mathrm{Q}_{\mathrm{Si}}=$ hourly solar gains $(\mathrm{Wh})$

$\mathrm{Q}_{\mathrm{Oi}}=$ hourly internal gains $(\mathrm{Wh})$

These indexes are designed to be as simple as possible to let designers use them [44]. As the parametric model separately calculates the solar gains for each façade, it is possible to obtain the thermal load at any time for each orientation. This may be useful to verify the balance between the gains and losses at solar peak hour during the winter to take advantage of building thermal inertia.

Galapagos find the $D_{\text {COOL }}$ values that minimise the cooling demand while $\mathrm{D}_{\text {HEAT }}$ is automatically calculated, showing the building hourly thermal behaviour for a typical winter day. The building shape will vary, according to the GA feedback in an iterative process. The automation loop can be interrupted by the user, or otherwise finishes when the system reaches its termination criteria. Our available hardware is not robust enough to include EnergyPlus in the loop. Therefore, the user enables DIVA to use EnegyPlus to calculate heating and cooling demand of the optimal pool of solutions. Based on energy demand, the model calculates energy use intensity (EUI), savings and construction costs of the pool of selected options. Retrofit cost and energy saving results are exported to Microsoft Excel ${ }^{\mathrm{TM}}$ to calculate the Net Present Value (NPV), and evaluate the financial performance of the selected options. A Pareto rank maximises only the positive NPV options and selects the best ones [45].

This methodology has been partially tested to calculate the window area per orientation optimizing heating demand in a house that we projected and built in 2012 [46]. We also tested our results of a typical winter day heating demand with the ones of an audited house, before and after retrofit [47].

\subsection{Building parameters}

In this parametric workflow, we distinguish three kinds of parameters: driving, fixed, and driven. Driving parameters like envelope U-values are the genes, which breed the GA. Fixed parameters as climate data are constant inputs that are not affected by the optimization process. Driven parameters such as insulation thickness are the result of the interaction of the two former ones.

As the model runs within Rhinoceros ${ }^{\mathrm{TM}}$ and Grasshopper $(\mathrm{GH})$, the building shape must be parametrically drawn in $\mathrm{GH}$. When imported from other CAD tools, as SketchUp ${ }^{\mathrm{TM}}$ or AutoCad ${ }^{\mathrm{TM}}$, since it is not parametrically generated, it is not possible to explore its morphology. In our model, the masses assemble, following simple topological rules to compose the building. While their length, width and height can vary within a range, the whole shape maintains a constant useful area, as it is commonly required. Each façade has a user-defined window to wall ratio (WWR), according to design recommendations given by the Argentine Institute for Normalization and Certification [48] in Argentina and the Spanish Building Code (SBC) [3] in the case of Spain. The model also requires roof, outer wall and window U-values, defined in ranges, from the minimum indicated in the corresponding standard to the maximum level according to the designer criteria. We also need the window infiltration rate, and the window solar heat gain coefficient (SHGC). The user assigns absorptivity values to opaque elements.

The designer fixes occupancy schedule and lighting load that depend on the building use(s) to determine internal gains. Heating and cooling set points are fixed to achieve indoor comfort at the levels recommended by current standards. The model calculates the hourly energy demand for a typical winter and summer day to analyse the envelope performance in real time and in a transparent workflow.

\subsection{Climate parameters}

The user feeds the parametric model with the mean maximum and minimum temperatures, available in any reliable database, or as in our case study, from the Weather Underground website [49]. The solar radiation for each façade orientation is available in the Andalusian Energy Agency website [50], and the monthly mean absolute humidity in January (winter) and July (summer), together with the annual mean wind speed [51], are available in the Spanish Meteorological Agency (AEMET). We considered the 2007/2016 period. The model corrects wind speed according to the building height if it exceeds $10 \mathrm{~m} \mathrm{[52].}$

\subsection{Multi-objective optimisation}

The values to optimise are the cooling demand and the financial performance. The scheme to optimise these contrasting goals utilises GHís evolutionary solver, Galapagos, for the energy demand and a Pareto rank for the financial performance. The evolutionary solver optimises only the heating and cooling demand, because it is a mono-objective algorithm [33]. When applied to a building retrofit, as the shape and WWR do not vary, the feedback data only modifies the envelope composition parameters. Then, GH connects to EnergyPlus through DIVA to calculate the energy demand of the optimised pool of solutions. We obtain the cost of the optimised pool and calculate the NPV for each one. A Pareto rank optimises the alternatives, maximising savings and NPV of each other. 


\subsection{Objective function: $D_{\mathrm{COOL}}$ minimisation}

By default Galapagos minimises the index $\mathrm{D}_{\mathrm{COOL}}$ while $\mathrm{D}_{\mathrm{HEAT}}$ is automatically calculated. In this transparent process, the user may switch to $\mathrm{D}_{\text {HEAT }}$ minimisation, by running another Galapagos command button connected to this index, on the Grasshopper canvas. If this is the case, $\mathrm{D}_{\mathrm{COOL}}$ is automatically calculated. In this way, the user can optimise each index alternatively and observe the envelope behaviour. The driving parameters - the genes that breed the GA - are mass dimensions and assemblage, WWR, envelope Uvalues, SHGC and opaque elements absorptivity. As optimisation process during BPS runs may be time-consuming and labourintensive, this model uses a quasi-steady state method within $\mathrm{GH}$. This is possible because of the high correlation between these indexes and the annual energy demand calculated with EnergyPlus $-\mathrm{R}^{2}>0.94$ for $\mathrm{D}_{\mathrm{COOL}}$ and $\mathrm{R}^{2}>0.85$ for $\mathrm{D}_{\text {HEAT }}$ - as shown in previous research where the indexes are explained in detail [53].

\subsection{Heating and cooling demand: DIVA+ EnergyPlus}

GH connects to EnergyPlus through DIVA ${ }^{\mathrm{TM}}$ [54] to simulate the energy performance of the optimised options. DIVA requires setting certain parameters to run the simulation: heating and cooling set point, light intensity, occupancy schedule, envelope U-values, window SHGC and building geometry. With these data, the program calculates the annual heating and cooling demand in separate runs, because SHGC changes when the shading device is open (heating season) or close (cooling season). The shading device allows solar radiation inside the building in heating season and prevents it in cooling season.

\subsection{Objective function: financial performance}

The scope of including the Net Present Value as an indicator of financial performance is to evaluate the potential morphological solutions, considering estimated construction costs and prospective revenues. NPV relates construction, operation costs and prospective incomes for a certain time span. The construction costs are extracted from the building shape, to calculate material quantities and their respective user provided unit prices or default cost settings. Operation costs do not include equipment performance because the intention is to evaluate only the heating and cooling demand and the subsequent investment.

Energy efficiency measures are expected to be cost effective and feasible, when considering their financial performance. The Net Present Value requires the input of the time cash flow span, the annual rate of return, the construction and operation costs and the revenue (Eq.3). In the case of sustainable buildings, the energy savings are part of the revenue. The NPV will vary depending on the inputs for local market conditions. Then, we post-process the selected pool by a Pareto front rank to optimise the financial performance [19].

$$
\boldsymbol{N P V}=\left(\sum_{t=1}^{T} \boldsymbol{C}_{t} /(1+\boldsymbol{r})^{t}-\boldsymbol{C}_{0}\right)
$$

\footnotetext{
$\mathrm{NPV}=$ net present value $(€)$

$\mathrm{t}$ : time cash flow span (year) $=30$

$\mathrm{r}=$ annual rate of return

$\mathrm{C}_{0}=$ construction cost $(€)$

$\mathrm{C}_{\mathrm{t}}=$ revenue-operation cost $(€)$
}

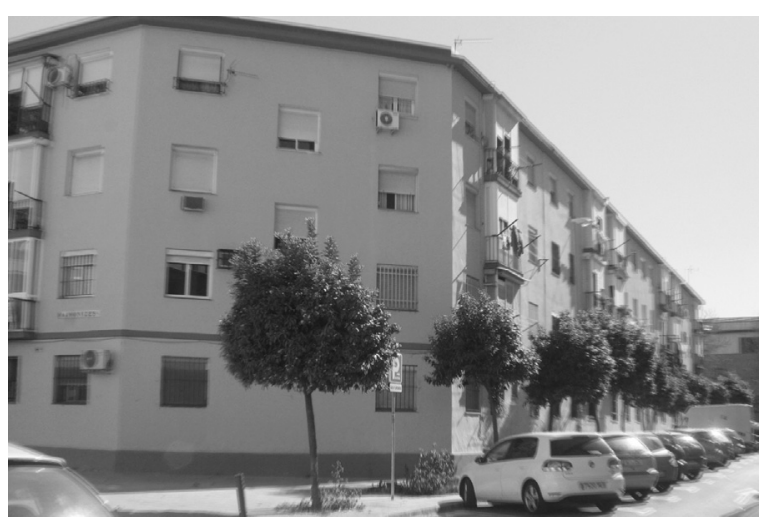

Fig. 2. SW view of the case study.

\section{Case study: housing building retrofit in seville, Spain}

\subsection{Building description}

The case study is a social housing block situated in Seville, built in the 150 s, for the railway company (RENFE) employees. It consists of forty apartments distributed in a 4-storey block that accounts for $3500 \mathrm{~m}^{2}$. The construction system is the traditional one in Andalusia [55]. The load-bearing walls are made of solid brick with cement mortar in both faces and no thermal insulation. The floor and roof slabs are made of ceramic blocks and reinforced concrete beams. The terrace is finished with ceramic tiles. The building has wooden window frames with single pane glazing and its WWR is $19.8 \%$ [56] (Fig. 2).

This building partially collapsed in 2010 when the works to build the Physiotherapy and Nursery School began in a plot of land just in front of our case study. When excavations began, a buried concrete wall that was bearing the subsoil broke. Because of this and the alluvial origin of the soil, the building foundations shifted. In consequence, many structural cracks appeared in walls, floors and roofs, and the inhabitants had to be evacuated and relocated until the retrofit finished.

As the Spanish Building Code (SBC) [57] compels to adequate existing buildings to EPBD standards when the refurbishment exceeds $25 \%$ of its area, it should have been retrofitted to energy efficiency. However, the insurance company did not comply with current regulations and only accepted to pay a retrofit to recover the buildingís former state. In our case study, we presumed a hypothetical retrofit to evaluate different kinds of envelope regarding energy demand and initial retrofit cost, utilizing the MOOM adapted for a retrofit case.

\subsection{Climate data}

Climate in Seville is temperate with mean temperatures of $11.8^{\circ} \mathrm{C}$ in winter and $27^{\circ} \mathrm{C}$ in summer. Rainfall accounts for $539 \mathrm{~mm} / \mathrm{year}$, the mean relative humidity is $59 \%$ and there are approximately 129 clear days a year (Table 1 ). Hourly mean temperatures oscillate between $8^{\circ} \mathrm{C}$ and $14.3^{\circ} \mathrm{C}$ in January and $20.57{ }^{\circ} \mathrm{C}$ and $35.83^{\circ} \mathrm{C}$ in July (Fig. 3) [51]. We considered the 2007/2016 period [49] to calculate mean temperatures. Hourly solar radiation (Figs. 4 and 5) determines sol-air temperatures and solar gains [50].

\subsection{Building parameters}

The fixed parameters comprehend building shape and envelope, WWR, standard minimum U-values, minimum infiltration rate, occupancy schedule, artificial lighting intensity, cooling and heating set points [58]. We adopted the data provided by Alba [59] 
Table 1

Seville climate data.

\begin{tabular}{ll}
\hline Meteorological station & Seville Airport \\
\hline Latitude & $37^{\circ} 25^{\prime} 0^{\prime \prime} \mathrm{N}$ \\
Longitude & $5^{\circ} 52^{\prime} 45^{\prime \prime}$ \\
Height above sea level & $34 \mathrm{~m}$ \\
Heating set point & $20^{\circ} \mathrm{C}$ \\
Cooling set point & $25^{\circ} \mathrm{C}$ \\
Winter design temperature & $0.6^{\circ} \mathrm{C}$ \\
Summer design temperature & $39^{\circ} \mathrm{C}$ \\
Heating degree days & 1198 \\
Cooling degree days & 855 \\
\hline
\end{tabular}

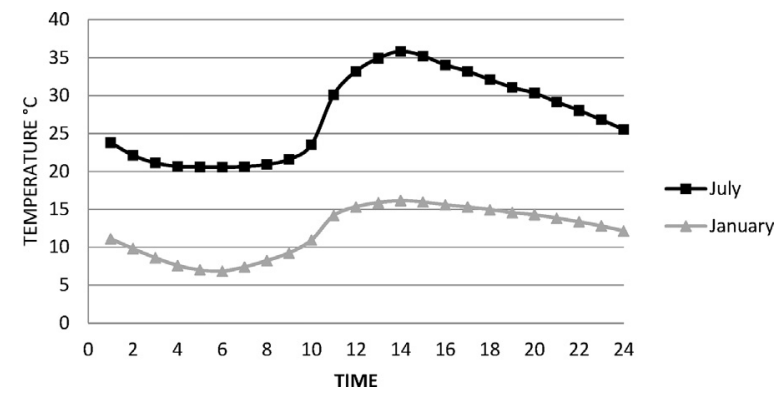

Fig. 3. Hourly mean temperatures for Seville in January and July.

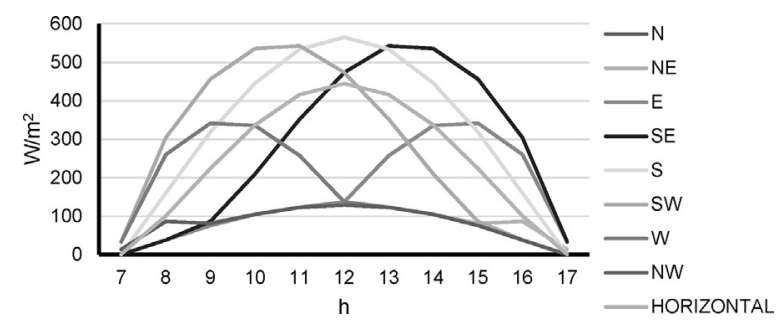

Fig. 4. Hourly global solar radiation for Seville in January.

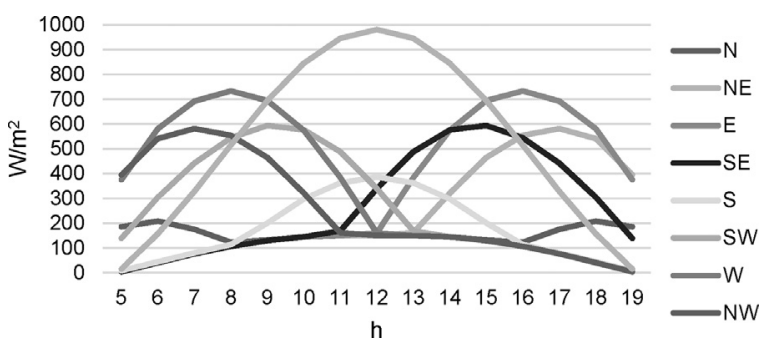

Fig. 5. Hourly global solar radiation for Seville in July.

to calculate current building envelope $U$-values and adequate the envelope to SBC standards for Seville, situated in the B4 climatic zone (Table 2) [60]. The envelope $U$-value requires the addition of façade/roof insulation and window replacement to achieve SBC standards. The façade insulation system adopted for the retrofit is the External Insulation Finishing System (EIFS) [61] and an inverted system is used for the roof. To calculate the budget for the initial outlay, we obtained the values from the Andalusian Construction Costs Database [62].

One of the driving parameters or genes is the insulation thickness in external walls and roofs. We considered a range from $0.1 \mathrm{~cm}$ to $34 \mathrm{~cm}$ Expanded Polystyrene for the roof and from 0.1 to $8 \mathrm{~cm}$ for walls (Table 3 ).

The other driving parameters are window U-values and SHG. As Galapagos is fed with a continuous range for the window U-value, we divide this range into three values, according to the three types. We select two types for glazing and frame material to replace the existing windows (Table 4) [63]. SHGC is automatically switched according to the corresponding window type and shading device position.

Type 0 is the current window type but as it does not reach the SBC minimum U-value (Table 2), we only consider it to calculate the energy demand of the option called current.

\subsection{Thermal load indexes}

$\mathrm{D}_{\text {HEAT }}$ and $\mathrm{D}_{\text {COOL }}$ consider the balance between thermal gains and losses in a typical winter and a summer day, as explained in (Eqs. (1) and (2)). Though they are not transient methods, they add solar and internal gains to transmission and ventilation thermal loads, becoming a quasi-steady state method.

As mentioned in 3.2, we consider the mean hourly temperatures (2007/2016) (Fig. 2) and the hourly solar radiation for January and July to calculate the sol-air temperatures. We switch SHGC if the shading device is open for heating or close for cooling demand (Table 4), in separate EnergyPlus runs.

Apart from solar gains, internal gains constitute the other source of heat in summer as well as in winter. Occupancy schedule considers 0.1 people $/ \mathrm{m}^{2}$ during the whole day. Artificial lighting intensity is $8 \mathrm{~W} / \mathrm{m}^{2}$ but equipment gains are not included. Ventilation rate is $0.8 / \mathrm{h}$. Indoor comfort temperature is $20^{\circ} \mathrm{C}$ in winter and $25^{\circ} \mathrm{C}$ in summer.

\section{Results and discussion}

\subsection{Energy performance optimisation}

The optimisation process has into two steps: minimising the energy demand and maximising the Net Present Value and savings. As they are competing objectives, a GA and a Pareto rank solve each of them. For the energy demand, we employ Galapagos, the GH genetic solver. Galapagos runs for 100 generations, with $75 \%$ inbreeding, 5\% maintaining and an initial population of two. The genes that feed the GA are the envelope U-values and the window SHGC. In the case of walls and roof, only the insulation thickness varies independently in each case, while the other envelope components do not change. The fitness value is the minimum $\mathrm{D}_{\mathrm{COOL}}$ index. We select the best 30 optimal options and three non-optimal ones: CURRENT, SBC and MAX INS options.

Table 2

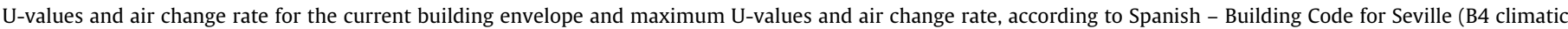
zone).

\begin{tabular}{|c|c|c|c|c|}
\hline \multirow[t]{2}{*}{ Condition } & \multicolumn{3}{|l|}{ U-values } & \multirow[t]{2}{*}{ Air change rate } \\
\hline & $\begin{array}{l}\text { Outer walls } \\
\mathrm{W} / \mathrm{m}^{2} \mathrm{~K}\end{array}$ & $\begin{array}{l}\text { Roof } \\
\mathrm{W} / \mathrm{m}^{2} \mathrm{~K}\end{array}$ & $\begin{array}{l}\text { Windows } \\
\mathrm{W} / \mathrm{m}^{2} \mathrm{~K}\end{array}$ & \\
\hline Current building envelope & 2.12 & 1.11 & 5.7 & 2.0 \\
\hline Spanish building code B4 climatic zone & 1 & 0.65 & 4.2 & 0.8 \\
\hline
\end{tabular}

Source: Alba, M; SBC. DB HE 
Table 3

Roof and external wall insulation.

\begin{tabular}{|c|c|c|c|c|c|}
\hline Insulation & $\begin{array}{l}\delta \\
\mathrm{kg} / \mathrm{m}^{3}\end{array}$ & $\begin{array}{l}\lambda \\
\mathrm{W} / \mathrm{mK}\end{array}$ & $\begin{array}{l}\text { U-value } \\
\mathrm{W} / \mathrm{m}^{2} \mathrm{~K}\end{array}$ & $\begin{array}{l}\text { EPS thickness } \\
\mathrm{cm}\end{array}$ & $\begin{array}{l}\text { Cost } \\
€ / \mathrm{cm} \mathrm{m}^{2}\end{array}$ \\
\hline roof & 15 & 0.0375 & $0.65 / 0.16$ & $2 / 34$ & 2.60 \\
\hline external wall & 15 & 0.0375 & $1 / 0.383$ & $2 / 8$ & 2.60 \\
\hline
\end{tabular}

Table 4

Selected window types: opening system, U-values, SHGC, frame and glass material, thermal break and costs.

\begin{tabular}{|c|c|c|c|c|c|c|c|c|}
\hline Window type & Opening system & $\begin{array}{l}\text { U-value } \\
\mathrm{W} / \mathrm{m}^{2} \mathrm{~K}\end{array}$ & $\begin{array}{l}\text { SHGC } \\
\text { Sd:open }\end{array}$ & $\begin{array}{l}\text { SHGC } \\
\text { Sd: close }\end{array}$ & Frame & Glass & Thermal break & $\begin{array}{l}\text { Cost } \\
€ / \mathrm{m} 2\end{array}$ \\
\hline 0 & sliding & 5.7 & 0.69 & 0.35 & wooden & Single pane & & 163.42 \\
\hline 1 & hinged & 4.2 & 0.62 & 0.35 & wooden & Double pane $4+6+4$ & $\mathrm{X}$ & 148.8 \\
\hline 2 & hinged & 3.2 & 0.62 & 0.35 & $\mathrm{Al}$ & Double pane $4+6+4$ & $\mathrm{X}$ & 232.9 \\
\hline 3 & hinged & 2.3 & 0.52 & 0.35 & $\mathrm{Al}$ & Double pane $4+6+4$ low $E$ & $\mathrm{X}$ & 302.38 \\
\hline
\end{tabular}

References: SHGC: solar heat gain coefficient, Sd: shading device.

\subsection{Building energy demand: DIVA/EnergyPlus}

After running Galapagos, DIVA ${ }^{\mathrm{TM}}$ joins GH to EnergyPlus to calculate annual cooling and heating demand of the optimal solutions. EnergyPlus also simulates the current building without any applied energy-efficiency measure, and the so-called SBC option. This option considers the minimum envelope U-values to comply with the Spanish Building Code. We propose another non-optimised option which considers maximum U-values: $8 \mathrm{~cm}$ thickness EPS on walls and $34 \mathrm{~cm}$ thickness EPS on roof (MAX INS option). Table 5 shows the adopted parameters. Table 6 shows $\mathrm{D}_{\mathrm{HEAT}}, \mathrm{D}_{\mathrm{COOL}}$, envelope U-values, window types, wall and roof insulation thickness, heating and cooling demand (EnergyPlus), EUI, and retrofit cost for the CURRENT, MAX INS and SBC options, and the 30 optimal options.

The GA optimised pool shows a spread of the solutions into two groups: one, which has EUI values from 67.29 to $75.95 \mathrm{kWh} / \mathrm{m}^{2}$ year and another, which has EUI values from 63.56 to $69.85 \mathrm{kWh} / \mathrm{m}^{2}$ year (Fig. 6). They differ from their retrofit costs.
Table 5

EnergyPlus parameters in DIVA.

\begin{tabular}{ll}
\hline Parameters & \\
\hline Heating Set Point & $20^{\circ} \mathrm{C}$ \\
Cooling Set Point & $25^{\circ} \mathrm{C}$ \\
Occupancy Type & Residential \\
Density & $0.1 \mathrm{p} / \mathrm{m}^{2}$ \\
Lighting Load & $8 \mathrm{~W} / \mathrm{m}^{2}$ \\
\hline
\end{tabular}

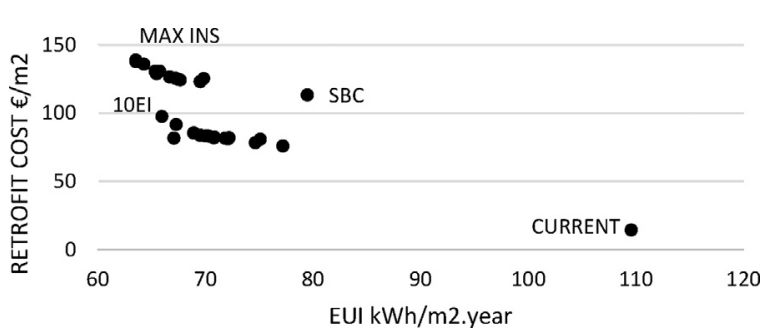

Fig. 6. EUI/retrofit cost relation for all options.

Table 6

Non-optimal options and GA minimised $\mathrm{D}_{\mathrm{COOL}}$ and $\mathrm{D}_{\mathrm{HEAT}}$ indexes, envelope U-values, insulation thickness, EUI and retrofit cost.

\begin{tabular}{|c|c|c|c|c|c|c|c|c|c|c|}
\hline \multirow[t]{2}{*}{ Options } & \multirow{2}{*}{$\begin{array}{l}D_{\text {HEAT }} \\
\mathrm{kWh} / \mathrm{m}^{2} \text { day }\end{array}$} & \multirow{2}{*}{$\begin{array}{l}D_{\mathrm{COOL}} \\
\mathrm{kWh} / \mathrm{m}^{2} \text { day }\end{array}$} & \multicolumn{2}{|l|}{ Window } & \multicolumn{2}{|l|}{ Wall } & \multicolumn{2}{|l|}{ Roof } & \multirow{2}{*}{$\begin{array}{l}\text { EUI } \\
\mathrm{kWh} / \mathrm{m}^{2} \text { year }\end{array}$} & \multirow{2}{*}{$\begin{array}{l}\text { Retrofit } \\
\text { cost } \\
€ / \mathrm{m}^{2}\end{array}$} \\
\hline & & & $\begin{array}{l}\text { U-value } \\
\mathrm{W} / \mathrm{m}^{2} \mathrm{~K}\end{array}$ & type & $\begin{array}{l}\text { U-value } \\
\mathrm{W} / \mathrm{m}^{2} \mathrm{~K}\end{array}$ & $\begin{array}{l}\text { EPS } \\
\mathrm{cm}\end{array}$ & $\begin{array}{l}\text { U-value } \\
\mathrm{W} / \mathrm{m}^{2} \mathrm{~K}\end{array}$ & $\begin{array}{l}\text { EPS } \\
\mathrm{cm}\end{array}$ & & \\
\hline CURRENT & 686.79 & 1201.31 & 5.7 & 0 & 2.11 & 0 & 1.11 & 0 & 109.55 & 14,46 \\
\hline MAX INS & 286.62 & 705.06 & 2.3 & 3 & 0.38 & 8 & 0.10 & 34 & 63.55 & 138,93 \\
\hline$S B C$ & 378.32 & 812.94 & 4.2 & 2 & 1 & 2 & 0.65 & 2.4 & 79.48 & 113,36 \\
\hline opt. 1 & 369.03 & 830.74 & 3.2 & 1 & 0.43 & 7 & 0.36 & 7 & 70.27 & 83,23 \\
\hline opt. 2 & 369.18 & 829.25 & 3.2 & 1 & 0.44 & 6.7 & 0.33 & 8.1 & 70.01 & 83,33 \\
\hline opt. 3 & 373.59 & 837.35 & 3.2 & 1 & 0.46 & 6.5 & 0.41 & 5.7 & 67.08 & 81,81 \\
\hline opt. 4 & 373.65 & 834.10 & 3.2 & 1 & 0.47 & 6.1 & 0.35 & 7.4 & 70.80 & 81,97 \\
\hline opt. 5 & 371.69 & 826.61 & 3.2 & 1 & 0.49 & 5.9 & 0.24 & 12.7 & 69.52 & 83,93 \\
\hline opt. 6 & 372.02 & 834.26 & 3.2 & 1 & 0.45 & 6.5 & 0.38 & 6.5 & 70.85 & 82,29 \\
\hline opt. 7 & 373.90 & 840.20 & 3.2 & 1 & 0.46 & 6.6 & 0.44 & 4.7 & 71.85 & 81,71 \\
\hline opt. 8 & 369.61 & 823.02 & 3.2 & 1 & 0.48 & 6 & 0.20 & 15.6 & 68.92 & 85,45 \\
\hline opt. 9 & 376.42 & 832.91 & 3.2 & 1 & 0.52 & 5.5 & 0.27 & 10.2 & 72.20 & 82,02 \\
\hline opt. 10 & 395.32 & 845.11 & 3.2 & 1 & 0.7 & 3.6 & 0.19 & 16.2 & 72.09 & 81,22 \\
\hline opt. 11 & 300.03 & 718.39 & 2.3 & 3 & 0.49 & 6 & 0.13 & 25 & 65.74 & 130,92 \\
\hline opt. 12 & 431.91 & 880.58 & 2.3 & 3 & 0.98 & 2 & 0.26 & 11 & 77.20 & 75,91 \\
\hline opt. 13 & 417.40 & 865.30 & 2.3 & 3 & 0.87 & 2.5 & 0.21 & 14.5 & 74.64 & 78,38 \\
\hline opt. 14 & 428.94 & 872.15 & 2.3 & 3 & 0.99 & 22.2 & 0.15 & 2 & 75.10 & 80,96 \\
\hline opt. 1EI & 368.74 & 891.99 & 3.2 & 1 & 0.43 & 7 & 0.36 & 7 & 70.21 & 83,33 \\
\hline opt. 3EI & 293.52 & 778.07 & 2.3 & 3 & 0.41 & 7.3 & 0.21 & 14.8 & 65.48 & 128,94 \\
\hline opt. 6EI & 291.12 & 709.45 & 2.3 & 3 & 0.42 & 7.2 & 0.11 & 30.9 & 64.29 & 135,96 \\
\hline opt. 7EI & 294.84 & 716.67 & 2.3 & 3 & 0.43 & 7 & 0.19 & 16.6 & 65.51 & 129,12 \\
\hline opt. 8EI & 362.41 & 813.14 & 3.2 & 1 & 0.44 & 6.8 & 0.13 & 26.2 & 67.29 & 91,61 \\
\hline opt. 10EI & 354.83 & 805.18 & 3.2 & 1 & 0.38 & 8 & 0.1 & 34 & 65.96 & 97,49 \\
\hline opt. 11EI & 370.43 & 826.36 & 3.2 & 1 & 0.47 & 6.1 & 0.25 & 11.6 & 69.50 & 83,90 \\
\hline opt. 13EI & 295.99 & 715.70 & 2.3 & 3 & 0.45 & 6.6 & 0.15 & 21.8 & 65.33 & 130,74 \\
\hline opt. 14EI & 286.86 & 705.64 & 2.3 & 3 & 0.38 & 8 & 0.11 & 31 & 63.56 & 137,77 \\
\hline opt.15EI & 292.44 & 716.30 & 2.3 & 3 & 0.4 & 7.6 & 0.22 & 13.5 & 65.45 & 128,94 \\
\hline
\end{tabular}




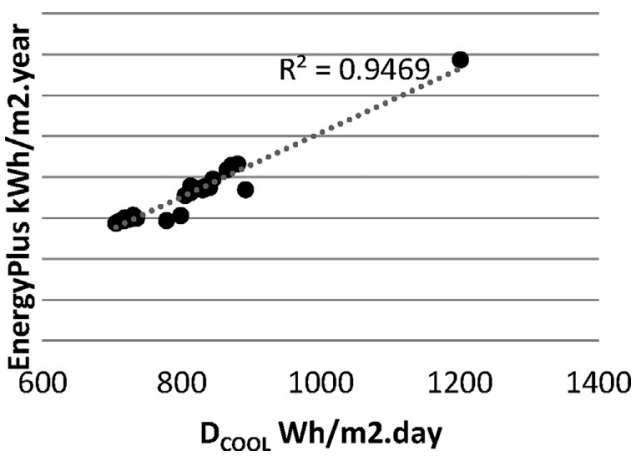

Fig. 7. Relation between $\mathrm{D}_{\mathrm{Cool}} /$ EnergyPlus EUI.

This could be a first criterion to select the first group but no savings or financial feasibility data support this decision.

The SBC option is expensive because it has type-2 windows that are not as efficient as type- 1 windows (Table 6 ). The MAX INS option is too expensive according to its energy performance. When we compare the retrofit cost with the EUI, we observe that the EUI decrement slows down as retrofit cost increases. The results show that we should consider more efficient windows than type-3 windows if we want to decrease EUI and not only increase insulation thickness.

\section{3. $D_{H E A T}-D_{C O O L} /$ EnergyPlus validation}

$\mathrm{D}_{\mathrm{COOL}}$ and $\mathrm{D}_{\text {HEAT }}$ are validated with EnergyPlus results. $\mathrm{D}_{\mathrm{COOL}}$ has a high coefficient of determination $\left(R^{2}=0.9469\right)$ with EnergyPlus annual energy demand (Fig. 7), and the same happens with $D_{\text {HEAT }} / D_{\text {COOL }}\left(R^{2}=0.9469\right)$. $D_{\text {HEAT }}$ has a lower coefficient of determination with EnergyPlus energy demand $\left(R^{2}=0.8719\right)$.

\subsection{Financial performance optimisation}

As shown above, financial feasibility determines the best final options. To optimise this objective function, NPV evaluates the financial performance of the options (Eq. (4)) with the data exported from GH to Microsoft Excel ${ }^{\mathrm{TM}}$. The cash flow time span is 30 years and the annual rate of return is $4 \%$. as recommended in the guidelines [64] that accompany Directive 2010/31/EU. The electricity cost to calculate savings is a weighted mean of the Spanish market: $0.125 € / \mathrm{kWh}$ [65].

$$
N P V=\sum_{t=1}^{T} \text { Savings } /(1+r)^{t}-\text { Retrofit cost (4) }
$$

NPV $=$ Net Present Value $(€)$

Savings $=$ difference between current and after-retrofit electricity expenses $(€)$

$\mathrm{t}=$ time span (years)

$r=$ annual rate of return $(\%)$

Retrofit cost $=$ initial outlay $(€)$

After the NPV calculation, negative NPV values are discarded (Table 7) and the Pareto rank only optimises the positive NPV options with the energy savings (Fig. 8).

The option SBC has shown a good energy performance $\left(79.8 \mathrm{kWh} / \mathrm{m}^{2}\right.$ year) (Table 6$)$ but a negative NPV (€ $\left.€ 169,161\right)$. It
Table 7

Electricity cost, savings and retrofit cost of positive NPV optimal solutions.

\begin{tabular}{lllll}
\hline options & $\begin{array}{l}\text { Electricity } \\
€\end{array}$ & $\begin{array}{l}\text { Savings } \\
€\end{array}$ & $\begin{array}{l}\text { Retrofit cost } \\
€\end{array}$ & $\begin{array}{l}\text { NPV } \\
€\end{array}$ \\
\hline opt. 3 & 29351.625 & 18582.9 & 286325 & 35010.69 \\
opt. $11 E I$ & 30407.5 & 17527.0 & 293638 & 34852.73 \\
opt. 5 & 30417.5 & 17517.0 & 293751 & 12111.45 \\
opt. 2 & 30630.5 & 17304.0 & 291667 & 11103.34 \\
opt. 4 & 30978.875 & 16955.6 & 286899 & 10814 \\
opt. 8 & 30155.625 & 17778.9 & 299086 & 10578.07 \\
opt. 6 & 30999.5 & 16935.0 & 288003 & 9410.59 \\
opt. 1 & 30745.625 & 17188.9 & 291305 & 7916.34 \\
opt. 10 & 31540.625 & 16393.9 & 284265 & 5293.11 \\
opt. 7 & 31435.625 & 16498.9 & 285987 & 5095.39 \\
opt. 9 & 31592.25 & 16342.3 & 287080 & 1728.67 \\
\hline
\end{tabular}

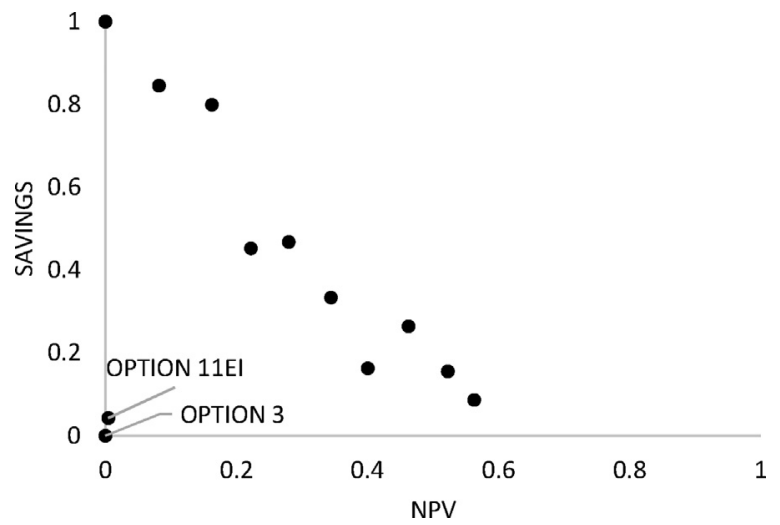

Fig. 8. Pareto rank of NPV/Savings positive-NPV options.

has type-2 windows, according to SBC minimum U-value, which are more expensive than type 1 but not so efficient.

The best solution is 3 , followed by $11 \mathrm{EI}$. Both options have type1 windows. The option-3 EUI is 3.48\% lower than for the option 11 . The wall EPS insulation increases from 6.1 to $6.5 \mathrm{~cm}$, and the roof EPS insulation decreases from 11.6 to $5.7 \mathrm{~cm}$ (Table 8). This means that the wall area has more incidence than the roof area on the energy demand because the building is not compact.

\section{Conclusions and future work}

As leading professionals, architects and DMs, have to deliver solutions based on scientifically sound performance analysis to achieve sustainable goals in a complex, and sometimes uncertain environment. MOOMs would ease decision making in energy efficiency investments because they estimate the best financial solution/s that will benefit the one who pays for the energy services.

We consider this method simple enough to encourage professionals to try it in the early stages of the design process as well as in building retrofit. As the methodology for performance-driven design is meant to address them, the workflow presented here does not require coding skills but parametric thinking [66], which is not frequent in conventional design methodologies. This could be a reliable tool to rapidly estimate the trade-off among competing aspects of a buildingís design, joining the input data with the best solutions in a bottom-up process.

Table 8

Best solution characteristics from Pareto rank.

\begin{tabular}{|c|c|c|c|c|c|}
\hline Options & Window Type & $\begin{array}{l}\text { Outer Wall Insulation } \\
\mathrm{CM}\end{array}$ & $\begin{array}{l}\text { Roof Insulation } \\
\text { CM }\end{array}$ & $\begin{array}{l}\text { EUI } \\
\mathrm{KwH} / \mathrm{m}^{2} \text { year }\end{array}$ & $\begin{array}{l}\text { Retrofit Cost } \\
€\end{array}$ \\
\hline 3 & 1 & 6.5 & 5.7 & 67.08 & 286,325 \\
\hline $11 E I$ & 1 & 6.1 & 11.6 & 69.50 & 296,638 \\
\hline
\end{tabular}


Regarding the results, the window type is the main determinant of the building energy and financial performance, and not the insulation thickness. The increment of insulation in walls and roofs improves energy performance but there are construction limitations to this increment. We also noticed that the SBC option, which accomplishes the Spanish Building Code minimum requirements, is not the most cost-effective in terms of energy demand and financial feasibility, as explained in 3.6.

This methodology needs to be tested with other building typologies, locations, and occupancy schedules. The next step is to test a wide range of housing buildings, and build a database with our indexes, to statistically study building behaviour in similar conditions. Furthermore, we have begun to add audits to improve the model calibration.

In future work, environmental costs should be added to reach Climate Change mitigation goals. $\mathrm{CO}_{2}$ emissions and Life Cycle Cost would make the financial feasibility of the presented options vary, as we expand our environmental sustainability perspective.

\section{Acknowledgments}

The authors wish to acknowledge Eric Denovitzer, Ayelén Denovitzer and María de la Paz Diulio for their help in proof reading the article.

This research did not receive any specific grant from funding agencies in the public, commercial, or not-for-profit sectors.

\section{References}

[1] Off. J. Eur. Union (2010) (EPBD recast: Directive 2010/31/EU on the energy performance of buildings).

[2] EIA, Annual Energyoutlook 2013 with Projections to 2040, 2013.

[3] J. Pinazo Ojer, M. José, Guía técnica de condiciones climáticas exteriores de proyecto, Instituto para la Diversificación y Ahorro de la Energía, Madrid, 2010 http://www.idae.es/uploads/documentos/documentos_12_Guia_tecnica condiciones_climaticas_exteriores_de_proyecto_e4e5b769.pdf.

[4] Buildings Performance Institute Europe, Cost Optimality. Discussing Methodology and Challenges Within the Recast Energy Performance of Buildings Directive, 2010

[5] P. Tuominen, K. Klobut, A. Tolman, A. Adjei, M. de Best-Waldhober, Energy savings potential in buildings and overcoming market barriers in member states of the European Union, Energy Build. 51 (2012) 48-55, http://dx.doi. org/10.1016/j.enbuild.2012.04.015.

[6] J. Tejedor, Nuevo paradigma normativo sobre la ciudad: Retornando a la ciudad tradicional, Inf. Constr. 67 (2015) 022

[7] A.-T. Nguyen, S. Reiter, P. Rigo, A review on simulation-based optimization methods applied to building performance analysis, Appl. Energy 113 (2014) 1043-1058, http://dx.doi.org/10.1016/j.apenergy.2013.08.061.

[8] M. Turrin, P. von Buelow, R. Stouffs, Design explorations of performance driven geometry in architectural design using parametric modeling and genetic algorithms, Adv. Eng. Inf. 25 (2011) 656-675, http://dx.doi.org/10. 1016/j.aei.2011.07.009.

[9] S.N. Murray, B.P. Walsh, D. Kelliher, D.T.J. O’Sullivan, Multi-variable optimization of thermal energy efficiency retrofitting of buildings using static modelling and genetic algorithms - A case study, Build. Environ. 75 (2014) 98-107, http://dx.doi.org/10.1016/j.buildenv.2014.01.011.

[10] S. Bambardekar, U. Poerschke, The architect as performer of energy simulation in the early design stage, Proc. 11th Int. IBPSA Conf., IBPSA, Glasgow (2009) 1306-1313, http://www.ibpsa.org/proceedings/BS2009/ BS09_1306_1313.pdf (Accessed March 21, 2017).

[11] S. Attia, J.L.M. Hensen, L. Beltrán, A.D. Herde, Selection criteria for building performance simulation tools: contrasting architects' and engineers' needs, J. Build. Perform. Simul. 5 (2012) 155-169, http://dx.doi.org/10.1080/ 19401493.2010.549573.

[12] D.A. Coley, S. Schukat, Low-energy design: combining computer-based optimisation and human judgement, Build. Environ. 37 (2002) 1241-1247, http://dx.doi.org/10.1016/S0360-1323(01)00106-8.

[13] J. López, Optimización Multi-objetivo. Aplicaciones a Problemas Del Mundo Real., Tesis Doctoral, Facultad de Informática- Universidad Nacional de La Plata, 2013.

[14] J.E. Harding, P. Shepherd, Meta-Parametric design, Des. Stud. (2016), http:// dx.doi.org/10.1016/j.destud.2016.09.005.
[15] S.J. Russell, Artificial Intelligence: A Modern Approach, global ed. of 3rd revised ed., Pearson Education, Boston Columbus Indianapolis New York San Francisco, 2016.

[16] J. Holland, Adaptation in natural and artificial systems: an introductory analysis with applications to biology, control, and artificial intelligence, MIT Press, Cambridge, Mass [etc. 2001.

[17] M. Mitchell, An Introduction to Genetic Algorithms, MIT, Cambridge Mass, London, 2006.

[18] J.A. Wright, H.A. Loosemore, R. Farmani, Optimization of building thermal design and control by multi-criterion genetic algorithm, Energy Build. 34 (2002) 959-972, http://dx.doi.org/10.1016/S0378-7788(02)00071-3.

[19] L. Caldas, Generation of energy-efficient architecture solutions applying GENE_ARCH: An evolution-based generative design system, Adv. Eng. Inform. 22 (2008) 59-70, http://dx.doi.org/10.1016/j.aei.2007.08.012.

[20] US Department of Energy, Building Technologies Office: EnergyPlus Energy Simulation Software, 2015, http://apps1.eere.energy.gov/buildings/ energyplus/ (Accessed March 21, 2017).

[21] T. Méndez Echenagucia, A. Capozzoli, Y. Cascone, M. Sassone, The early design stage of a building envelope: multi-objective search through heating, cooling and lighting energy performance analysis, Appl. Energy 154 (2015) 577-591, http://dx.doi.org/10.1016/j.apenergy.2015.04.090.

[22] D. Gerber, E. Lin, Designing-in performance: a framework for evolutionary energy performance feedback in early stage design, Autom. Constr. 38 (2014) 59-73, http://dx.doi.org/10.1016/j.autcon.2013.10.007.

[23] P. Cook, Rhinoceros v5.0, Level 1, Training Manual, Robert McNeel \& Associates, Seattle, 2013.

[24] A. Payne, R. Issa, The Grasshopper Primer, 2nd edition, Lift Architects, USA, 2009 https://static1.squarespace.com/static/51c6f9f3e4b0e47ad1bbc71c/t/ 521cf940e4b021571fc7d3a5/1377630528615/Grasshopper+Primer_ Second+Edition_090323.pdf.

[25] D.J. Gerber, E. Pantazis, A. Wang, A multi-agent approach for performance based architecture: design exploring geometry, user, and environmental agencies in façades, Autom. Constr. 76 (2017) 45-58, http://dx.doi.org/10. 1016/j.autcon.2017.01.001.

[26] E. Asadi, M.G. da Silva, C.H. Antunes, L. Dias, A multi-objective optimization model for building retrofit strategies using TRNSYS simulations, GenOpt and MATLAB, Build. Environ. 56 (2012) 370-378, http://dx.doi.org/10.1016/j. buildenv.2012.04.005.

[27] M. Ferrara, E. Fabrizio, J. Virgone, M. Filippi, A simulation-based optimization method for cost-optimal analysis of nearly Zero Energy Buildings, Energy Build. 84 (2014) 442-457, http://dx.doi.org/10.1016/j.enbuild.2014.08.031.

[28] M. Rahmani Asl, S. Zarrinmehr, M. Bergin, W. Yan, BPOpt A framework for BIM-based performance optimization, Energy Build. 108 (2015) 401-412, http://dx.doi.org/10.1016/j.enbuild.2015.09.011.

[29] D. Rutten, Galapagos on the logic and limitations of generic solvers, Archit. Des. 83 (2013) 132-135, http://dx.doi.org/10.1002/ad.1568.

[30] K. Lagios, J. Niemasz, C. Reinhardt, Animated building performance simulation (ABPS) linking Rhinoceros/Grasshopper with Radiance/DaySim, Proc. Fourth Int. Conf. IBPSA, New York (2010).

[31] J. González, F. Fiorito, Daylight design of office buildings: optimisation of external solar shadings by using combined simulation methods, Buildings 5 (2015) 560-580, http://dx.doi.org/10.3390/buildings5020560.

[32] B. Ercan, S.T. Elias-Ozkan, Performance-based parametric design explorations: a method for generating appropriate building components, Des. Stud. 38 (2015) 33-53, http://dx.doi.org/10.1016/j.destud.2015.01.001.

[33] F. Calcerano, L. Martinelli, Numerical optimisation through dynamic simulation of the position of trees around a stand-alone building to reduce cooling energy consumption, Energy Build. 112 (2016) 234-243, http://dx. doi.org/10.1016/j.enbuild.2015.12.023.

[34] P. Camporeale, Genetic algorithms applied to urban growth optimization. Solar envelope and solar fan, Proc. 31 St Educ. Res. Comput. Aided Archit. Des. Eur. ECAADe Conf., Faculty of Architecture, Delft University of Technology, Delft (2013) 227-236 http://papers.cumincad.org/cgi-bin/works/ Search? search $=$ Camporeale $\& \mathrm{x}=37 \& \mathrm{y}=20$

[35] Geco, Food4Rhino. 2016 http://www.food4rhino.com/app/geco (Accessed March 21, 2017)

[36] P. Camporeale, Genetic algorithms applied to urban growth optimizing solar radiation, Proc. 29th Conf. Passive Low Energy Archit., Munich (2013) http:// plea-arch.org/ARCHIVE/2013/Conference\%20Papers/Session\%20V\%20Poster/ V.2\%20Regions,\%20Cities,\%20Neighborhoods\%20-\%20Tools\%202/genetic algorithms_applied_to_urban_growth_optimizing_solar_radiation.pdf.

[37] J.-T. Jin, J.-W. Jeong, Optimization of a free-form building shape to minimize external thermal load using genetic algorithm, Energy Build. 85 (2014) 473-482, http://dx.doi.org/10.1016/j.enbuild.2014.09.080.

[38] V. Granadeiro, J.R. Correia, V.M.S. Leal, J.P. Duarte, Envelope-related energy demand: a design indicator of energy performance for residential buildings in early design stages, Energy Build. 61 (2013) 215-223, http://dx.doi.org/10 1016/j.enbuild.2013.02.018.

[39] P. Depecker, C. Menezo, J. Virgone, S. Lepers, Design of buildings shape and energetic consumption, Build. Environ. 36 (2001)627-635, http://dx.doi.org/ 10.1016/S0360-1323(00)00044-5.

[40] P. Camporeale, J. Czajkowski, Environmental index of energy demand in buildings. Optimization of a parametric model, Int. J. Civ. Struct. Eng. 3 (2016) 82-87, http://dx.doi.org/10.15224/978-1-63248-093-4-17.

[41] G.E. Gonzalo, V.M. Nota, Manual de arquitectura bioclimática, 2003. 
[42] IRAM, IRAM 11659-1 Esquema 2. Aislamiento térmico de edificios. Verificación de sus condiciones higrotérmicas. Ahorro de energía en refrigeración. Parte 1: vocabulario, definiciones, tablas y datos para determinar la carga la carga térmica de refrigeración, (2004).

[43] IRAM, IRAM 11659-2. Proyecto 1 de Norma Argentina. Acondicionamiento térmico de edificio. Verificación de sus condiciones higrotérmicas. Ahorro de energía en refrigeración. Parte 2: Edificios para vivienda, (2007).

[44] X. Shi, W. Yang, Performance-driven architectural design and optimization technique from a perspective of architects, Autom. Constr. 32 (2013) 125-135, http://dx.doi.org/10.1016/j.autcon.2013.01.015.

[45] M. Karmellos, A. Kiprakis, G. Mavrotas, A multi-objective approach for optimal prioritization of energy efficiency measures in buildings: model, software and case studies, Appl. Energy 139 (2015) 131-150, http://dx.doi org/10.1016/j.apenergy.2014.11.023.

[46] P. Camporeale, El uso de algoritmos genéticos en el diseño paramétrico de edificios energéticamente eficientes: el coeficiente $\mathrm{G}$ y el consumo anual de energía, in: Actas XV Congr Ibérico X Congr. Iberoam. Energ. Sol., Manuel Vázquez Vázquez, Vigo, 2012.

[47] P. Camporeale, J. Czajkowski, Heating and cooling demand in buildings: comparison between a parametric model and an audited building, Proc III Int. V Natl. Conf. Sustain. Build. Eco-Effic. Solut., Pilar Mercader Moyano, Seville (2017).

[48] IRAM, IRAM 11603. Acondicionamiento térmico de edificios. Clasificación bioambiental de la República Argentina, Buenos Aires, Argentine Normalisation and Certification Institute, 2012.

[49] Weather Underground, Weather History for Sevilla, El Salvador, (n.d.). https:// www.wunderground.com/history/airport/LEZL/2016/1/1/CustomHistory. html? dayend=1\&monthend=1\&yearend=2017\&req_city=\&req_state=\&req statename $=\&$ reqdb.zip $=\&$ reqdb. magic $=\&$ reqdb. $w m o=\& M R=1$ (Accessed March 21, 2017).

[50] Agencia Andaluza de Energía, Radiación solar, (n.d.). http://www. agenciaandaluzadelaenergia.es/Radiacion/radiacion1.php (Accessed March 21, 2017).

[51] Agencia Estatal de Meteorología, Valores climatológicos normales: Sevilla Aeropuerto - Agencia Estatal de Meteorología - AEMET. Gobierno de España, (n.d.). http://www.aemet.es/es/serviciosclimaticos/datosclimatologicos/ valoresclimatologicos (Accessed March 21, 2017).

[52] Swiss Federal Office of Energy, Suisse Éole. The Swiss Wind Power Data Website, Wind Profile Calc. (2017). http://wind-data.ch/tools/profile.php (Accessed April 2, 2017).

[53] P. Camporeale, J. Czajkowski, Optimización de consumo energético de un modelo de diseño paramétrico, in: La Plata, 2016

[54] A. Jakubiec, C. Reinhardt, DIVA 2.0: integrating daylight and thermal simulations using rhinoceros 3D, DAYSIM and EnergyPlus, Proc. 12th Conf. Int. Build. Perform. Simul. Assoc., Sydney (2011) 2002-2009.

[55] M. Mercader Moyano. Cuantificación de los recursos consumidos y cuantificación de las emisiones de $\mathrm{CO} 2$ producidas en las construcciones de Andalucía y sus implicaciones en el Protocolo de Kioto, School of Architecture-University of Seville, 2010. http://fondosdigitales.us.es/tesis/ tesis/1256/cuantificacion-de-los-recursos-consumidos-y-emisiones-de-co2 producidas-en-las-construcciones-de-andalucia-y-sus-implicaciones-en-elprotocolo-de-kioto/.
[56] A. Ferreira, Recuperación De Viviendas En Condiciones De Emergencia. Estudio De Caso: Viviendas RENFE (Sevilla), University of Seville, 2015.

[57] Ministerio de Fomento, Documento Básico HE Ahorro de energía, in: Código Téc. Edificación, Secretaría de Estado de Infraestructuras, Transporte y Vivienda, Dirección General de Arquitectura, Vivienda y Suelo, Madrid, 2016. http://www.codigotecnico.org/images/stories/pdf/ahorroEnergia/DccHE.pdf.

[58] Ministerio de Fomento, DA DB-HE/1 Cálculo de parámetros característicos de la envolvente. Documento de Apoyo al Documento Básico DB-HE Ahorro de energía, in: Código Téc. Edificación, Ministerio de Fomento. Secretaría de Estado de Infraestructuras, Transporte y Vivienda. Dirección General de Arquitectura, Vivienda y Suelo., Madrid, 2015. http://www.codigotecnico.org images/stories/pdf/ahorroEnergia/DA-DB-HE-1-Calculo_de_parametros_ caracteristicos.pdf.

[59] M. Alba, Modelo de Evaluación de la viabilidad económica y ambiental de la recuperación de edificios. Aplicación en edificios residenciales de la ciudad de Sevilla, University of Seville, 2016.

[60] Ministerio de Fomento, Documento descriptivo climas de referencia, in: Código Téc. Edificación, Secretaría de Estado de Infraestructuras, Transporte y Vivienda. Dirección General de Arquitectura, Vivienda y Suelo, Madrid, 2017. https://www.codigotecnico.org/images/stories/pdf/ahorroEnergia/20170202DOC-DB-HE-0-Climas\%20de\%20referencia.pdf.

[61] BSD-146: EIFS - Problems and Solutions, Build. Sci. Corp. (n.d.). https:// buildingscience.com/documents/digests/bsd-146-eifs-problems-andsolutions (Accessed March 21, 2017).

[62] J. Barón, J. Conde, M. Osuna, A. Ramírez, J. Solís, Consejería de Fomento y Vivienda/Vivienda y Rehabilitación/Base de Costes de la Construcción de Andalucía (BCCA) 29abril 2016. Banco de precios., (2016). http://www. juntadeandalucia.es/fomentoyvivienda/portal-web/web/areas/vivienda/ texto/403b7931-0d21-11e6-a18a-052bf9b4a08b (Accessed March 21, 2017).

[63] Instituto Eduardo Torroja de Ciencias de la Construcción, CEPCO y AICIA, Catálogo de Elementos Constructivos del CTE, in: Código Téc. Esp., Madrid, 2010.

[64] Official Journal of the European Union, Guidelines accompanying Commission Delegated Regulation (EU) No 244/2012 of 16 January 2012 supplementing Directive 2010/31/EU of the European Parliament and of the Council on the energy performance of buildings by establishing a comparative methodology framework for calculating cost-optimal levels of minimum energy performance requirements for buildings and building elements, 2012

[65] J. Arbona, Precio kWh electricidad, Comparadorluz.Com. (2017). http:// comparadorluz.com/faq/precio-kwh-electricidad (Accessed March 21, 2017).

[66] F. Moussavi, Viewpoints: Farshid Moussavi on the need for parametric thinking, Archit. Rev. (2011),

https://www.architectural-review.com/rethink/viewpoints-farshidmoussavi-on-the-need-for-parametric-thinking/8620000. article (Accessed March 21, 2017) 